\title{
Komplikasi Kronik Benda Asing Pada Percabangan Bronkus
}

\author{
Russilawati Russilawati ${ }^{1}$, Oea Khairsyaf \\ ${ }^{1}$ Bagian Pulmonologi dan Kedokteran Respirasi Fakultas Kedokteran Universitas Andalas, Sumatera Barat, Indonesia \\ ${ }^{2}$ SMF Pulmonologi dan Kedokteran Respirasi RSUP. Dr. M. Djamil Padang, Sumatera Barat, Indonesia
}

\begin{abstract}
A B S T R A C T
Latar Belakang. Aspirasi benda asing ke dalam percabangan bronkus dapat mengancam jiwa terutama bila benda yang masuk cukup besar untuk menyebabkan penyumbatan. Di sisi lain benda kecil yang terhirup dapat melewati karina dan menyebabkan gejala dan komplikasi yang lebih ringan. Gejala kronik dan infeksi berulang yang menyebabkan bronkiektasis bisa terjadi karena keterlambatan evakuasi benda asing. Kami memaparkan kasus aspirasi paku pada pasien laki-laki 17 tahun yang datang dengan keluhan batuk darah. Pasien mempunyai riwayat menelan paku enam bulan sebelumnya dan tidak ada gejala apa-apa sampai seminggu sebelum masuk rumah sakit. Usaha pertama mengeluarkan paku dengan bronkoskopi rigid dalam anastesi umum gagal. Bronkoskopi lentur serat optik menemukan paku pada orifisium lobus kanan bawah dan CTscan toraks memperlihatkan adanya bronkiektasis pada distal dari letak paku. Ekstraksi menggunakan bronkoskopi lentur dengan anastesi lokal berhasil menarik paku ke laring yang selanjutnya menginduksi batuk dan paku berhasil dikeluarkan. Tidak ada gejala dan komplikasi lajutan setelah paku

further symptoms after the extraction. Eventhough aspiration small object cause no symptom, it could lead to chronic complication such as bronchiectasis. FOB for removing the object is supposed to perform carefully because the object could fall on another part of brochial tree when it was pulled out.

Keywords: Foreign Body, Bronchial Tree, Complication, Flexible Bronchoscopy

\section{Apa yang sudah diketahui tentang topik ini?}

Aspirasi benda asing ke dalam percabangan bronkus dapat mengancam jiwa terutama bila benda yang masuk cukup besar untuk menyebabkan penyumbatan. Di sisi lain benda kecil yang terhirup dapat melewati karina dan menyebabkan gejala dan komplikasi yang lebih ringan. Gejala kronik dan infeksi berulang yang menyebabkan bronkiektasis bisa terjadi karena keterlambatan evakuasi benda asing
\end{abstract} dikeluarkan. Meskipun aspirasi benda kecil tidak menyebabkan gejala, hal ini dapat menyebabkan komplikasi kronik seperti bronkiektasis. Evakuasi dengan bronkoskopi serat optik lentur harus dilakukan dengan hati-hati karena objek dapat terjatuh ke bagian lain percabangan bronkus ketika ditarik keluar.

Kata kunci: Benda Asing, Percabangan Bronkus, Komplikasi, Bronkoskopi Fleksibel

Background. Foreign body aspiration in tracheobronchial could be life threatening particularly if the object large enought to cause nearly complete obstruction. In the other hand small object could pass beyond carina and cause less severe sign and complication manifest. Chronic symptoms with recurrent infection that lead to brochiectasis may occur in delayed of extraction. We presented a case of nail aspiration by a 17 years old male patients who presented with hemoptysis. The patient had history of nail aspiration six months ago and had no symptom until the last one week. First attempt of evacuating used rigid bronchoscopy under general anesthesia had failed. Fiber optic bronchoscopy (FOB) found the nail at the orificium of right lower lobe and chest computed tomography stated the occurancy of bronchiectasis at distal of nail. The extraction was performed by FOB with local anesthesia succeeded to remove the nail to the laring that induced cough and nail threw out. There were no major complication and

\section{Apa yang ditambahkan pada studi ini?}

Benda asing yang berukuran kecil pada bagian distal jalan napas tidak menimbulkan gejala dalam waktu singkat tetapi dapat menyebabkan komplikasi kronik yang serius seperti bronkiektasis. Pada kasus ini brokiektasis timbul setelah 5-6 bulan setelah inhalasi paku. Evakuasi paku berhasil dilakukan dengan bronkoskopi serat optik lentur.

\section{CORRESPONDING AUTHOR}

Name: Russilawati Russilawati

Phone: +6281267122277

E-mail: russilawati@med.unand.ac.id

\section{ARTICLE INFORMATION}

Received: September $23^{\text {rd }}$, 2020

Revised: October $15^{\text {th }}, 2020$

Available online: October $31^{\text {st }}, 2020$ 


\section{Pendahuluan}

Aspirasi benda asing adalah masalah kesehatan di mana-mana yang sering menimbulkan komplikasi yang mengancam jiwa. ${ }^{1}$ Insiden ini menyebabkan sekitar 3000 kematian di Amerika Serikat setiap tahunnya. ${ }^{2}$ Sebagian besar aspirasi benda asing terjadi pada anak-anak kurang dari tiga tahun. ${ }^{1}$ Anak-anak canderung mengalami aspirasi ke saluran napas disebabkan karena elevasi laring dan penutupan glotis yang belum sempurna saat menelan. Benda-benda organik paling sering ditemukan seperti kacang dan bijibijian lainnya, akan tetapi materi anorganik seperti koin dan mainan juga ditemukan. ${ }^{2}$

Aspirasi benda asing pada dewasa jarang ditemukan, dan ini menyebabkan gejala yang tergantung pada lokasi tersangkutnya benda asaing tersebut pada percabangan bronkus. Obyek yang besar bisa meyumbat jalan napas secara keseluruhan yang selanjutnya mengakibatkan asfiksia dengan gagal napas akut. ${ }^{3}$ Pada kasuskasus penyumbatan tidak sempurna atau benda asing dapat melewati karina ke bagian yang lebih distal manifestasinya gejalanya lebih ringan. ${ }^{4}$ Keterlambatan dalam mengeluarkan benda asing tersebut bisa menyebabkan pneumonia postobstruktif, atelektasis, bronkiektasis dan pembentukan jaringan granulasi. ${ }^{3}$

\section{Laporan Kasus}

Pasien laki-laki 17 tahun dibawa ke instalasi gawat darurat karena batuk darah sejak seminggu yang lalu. Darah merah terang dengan volume satu sendok makan setiap batuk. Pasien telah menderita batuk berdahak sejak sebulan ini dan meningkat seminggu terakhir dengan dahak kental kekunigan. Pasien sebenarnya telah mengalami nyeri dada sejak enam bulan yang lalu setelah tanpa sengaja menelan paku. Sesak napas hanya dirasakan saat berkuat. Riawayat demam subfebris dalam seminggu terakhir. Tidak terdapat riwayat penyakit dahulu yang cukup bermakna. Pasien adalah pelajar sekolah menengah atas, belum menikah dan tidak mempunyai riwayat merokok maupun penyalahgunaan alkohol dan obat-obat terlarang.

Tanda-tanda vital pada pasien normal keculai napasnya yang meingkat 30 kali per menit. Suara napas melemah pada lapangan bawah paru kanan. Tidak ada kelainan lain yang menonojol. Rontgen toraks memperlihatkan adanya gambaran paku pada bagian sentral lobus bawah paru kanan (gambar.1). Pemeriksaan laboratorium mendapatkan hemoglobin $12,4 \mathrm{~g} / \mathrm{dL}$, leukosit $17.810 / \mathrm{dL}$, trombosit $608.000 / \mathrm{dL}, \mathrm{Na}+137 \mathrm{mmol} / \mathrm{L}, \mathrm{K}+4,9 \mathrm{mmol} / \mathrm{L}$, dan Cl- $106 \mathrm{mmol} / \mathrm{L}$.

Kami menyimpulkan bahwa pasien terinhalasi benda asing pada percabangan bronkus dengan kecurigaan kuat pada orifisium lobus kanan bawah dan juga mengalami pneumonia obstruktif. Antibiotik spektrum luas diberikan selama sepuluh hari yaitu ceftriaxon 2 gram per hari dan levofloksasin $750 \mathrm{mg}$ per hari. Setelah itu dilakukan CT scan toraks dan rontgen toraks ulang. Rontgen toraks ulang dan CT scan toraks memperlihatkan telah terdapat bronkiektasis pada lobus bawah paru kanan.
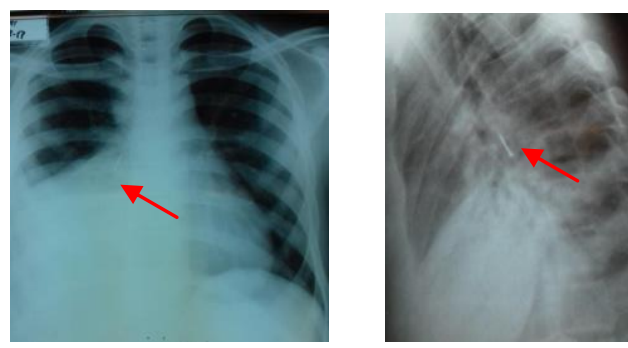

Gambar 1. Rontgen toraks posterio-anterior/lateral memperlihatkan gambaran paku (panah merah) dan perselubungan radio opaq pada bagian distal dari paku dengan sedikit penyempitan iga.

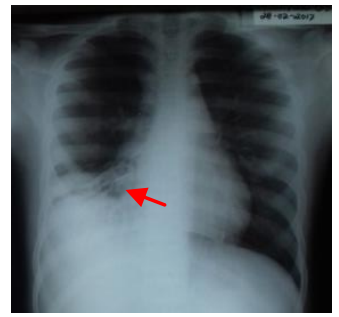

Gambar 2. Post pemberian antibiotik, terlihat infiltrat menipis dan gambara bronkiektasis terlokalisir pada lobus bawah paru kanan.

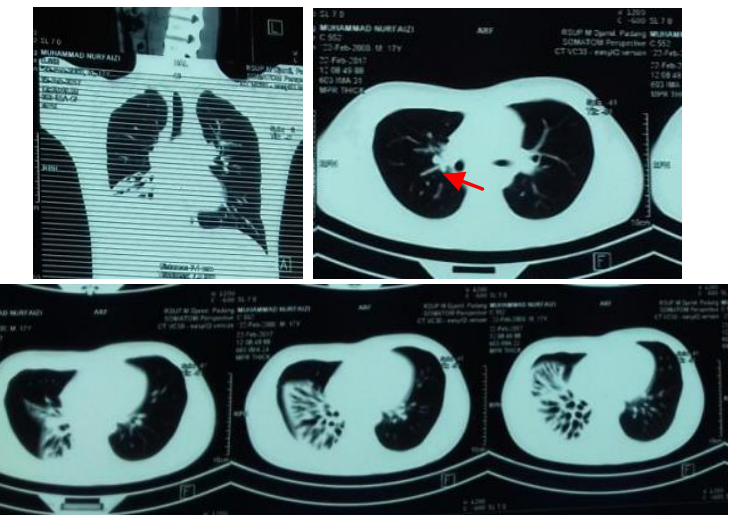

Gambar 3. Ct-Scan toraks memperlihatkan posisi paku dan gambaran bronkiektasis pada lobus bawah paru kanan. 
Rencana tindakan pada pasien tersebut adalah evakuasi dengan bronkoskopi rigid dalam anastesi umum. Usaha evakuasi gagal dilakukan karena posisi benda asing terlalu distal. Selanjutnya dilakukan pemeriksaan dan ekstraksi menggunakan bronkoskopi lentur dengan anastesi lokal. Paku terlihat pada orifisium lobus bawah paru kanan tertutupi oleh jaringan granulasi dan mukus kental. Ekstraksi dilakukan dengan menggunakan forsep aligator untuk menrik paku keluar dari percabangan bronkus. Saat mencapai laring dan pita suara paku tersangkut namun refleks batuk pasien terangsang sehingga paku bisa keluar dengan dibatukkan.Terdapat perdarahan ringan pada saat ekstraksi namun perdarahan bsa dikontrol dengan adrenalin 1 : 10.0000 . Tidak ada gejala sisa yang dikeluhkan pasien dalam pengamatan 3 bulan setelah paku dievakuasi.
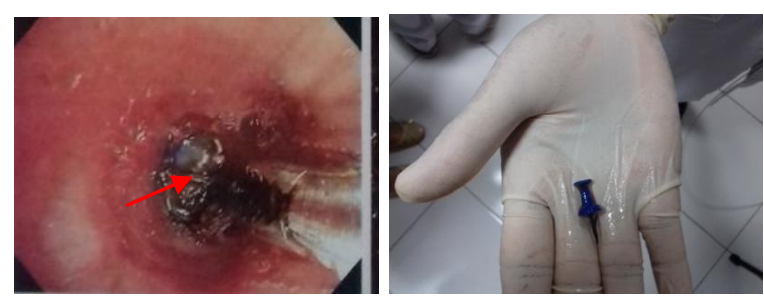

Gambar 4. Paku terlihat pada orifisium melalui kamera bronkoskopi lentur dilapisi jaringan granulasi dan mukus kental (kiri) dan paku yang berhasil dievakuasi (kanan)

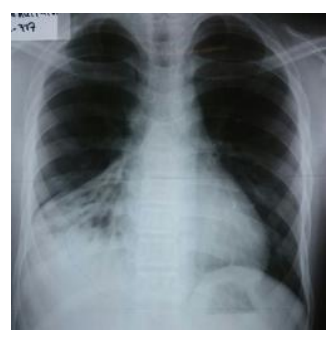

Gambar 5. Rontgen toraks posterio-anterior setelah evakuasi paku terlihat adanya bronkiektasis fokal pada lobus bawah kanan

\section{Diskusi}

Berbagai macam benda asing dapat terinhalasi dalam saluran napas yaitu trakhea, bronkus dan percabangannya. Keparahan gejala tergantung kepada lokasi, besarnya benda yang terinhalasi, komposisi dan lamanya benda asing tersebut barada dalam saluran napas. Benda asing yang kecil dapat melewati saluran napas atas dan tersangkut di bagian distal. Fase akut kondisi tersebut tidak akan menyebabkan gejala yang berat. Benda asing yang bersifat organik lebih berbahaya dibandingkan dengan benda-benda logam karena bisa menyebabkan reaksi lipoid yang berat. Semakin lama benda asing berada pada saluran napas semakin besar kemungkinannya untuk bermigrasi makin ke distal dan menimbulkan reaksi inflamasi dan granulasi dan impaksi. ${ }^{4}$

Benda kecil dalam saluran napas menyebabkan obstruksi parsial sehingga masih memungkinkan udara melewati saluran napas. Secara gradual dapat terbentuk bronkiektasis pada paru pasien yang disebabkan oleh iritasi kronik dan infeksi berulang pada bagian distal dari benda asing. Kondisi ini menjelaskankan munculnya batuk darah pada pasien setelah beberapa bulan. Beberapa kasus yang berat kondisi seperti ini memerlukan lobektomi untuk mengatasi batuk darahnya. ${ }^{4}$ Komplikasi jangka panjang terdapatnya benda asing pada percabangan bronkus yang lain mencakup abses, pneumonia dan emfisema obstruktif. ${ }^{5}$ Kasus ini memperlihatkan pentingnya kecurigaan adanya benda asing pada pasien dengan infeksi saluran napas bawah berulang yang responnya tidak adekuat terhadap terapi rutin. Gejala klasik yang dicurigai

Peran pencitraan dengan radiologi memainkan peran yang bervariasi dalam diagnostik. Sebagian besar benda asing tidak bersifat radiopak, ${ }^{5}$ namun dalam kasus ini benda asing yang terinhalasi adalah paku besi. Inhalasi benda-benda kecil seperti ini pada awalnya tidak menimbulkan gejala yang berat sehingga sering diabaikan seperti yang terjadi pada pasien dalam kasus ini. Pasien hanya merasakan nyeri dada yang tidak begitu berat selama enam bulan. Meskipun demikian sebulan terakhir pasien mulai batuk darah berulang dan dari rontgen toraks terlihat gambaran paku pada paru bawah kanan.

Bronkoskopi rigid merupakan prosedur standar untuk evakuasi benda asing, ${ }^{5}$ namun gagal pada kasus ini. Hal ini kemungkinan disebabkan oleh posisi benda asing di percabangan distal bronkus. Evakuasi benda asing pada kondisi ini sering dipersulit dengan adanya edema, sekresi, granulasi dan perdarahan. Selanjutnya kami melakukan prosedur evakuasi dengan bronkoskopi serat optic lentur. Tindakan ini berhasil menarik paku sampai ke laring dan merangsang refleks batuk pasien sehingga paku keluar saat pasien terbatuk. Observasi tiga bulan 
pada pasien ini tidak terlihat munculnya batuk darah maupun infeksi berulang, sehingga lobektomi tidak dilakukan pada pasien ini.

\section{Kesimpulan}

Benda asing yang berukuran kecil pada bagian distal jalan napas tidak menimbulkan gejala dalam waktu singkat tetapi dapat menyebabkan komplikasi kronik yang serius seperti bronkiektasis. Pada kasus ini brokiektasis timbul setelah 5-6 bulan setelah inhalasi paku. Evakuasi paku berhasil dilakukan dengan bronkoskopi serat optik lentur.

\section{Ucapan Terima Kasih}

Terima kasih kepada Instalasi Dianostik Terpadu RSUP. Dr. M. Djamil Padang.

\section{Daftar Pustaka}

1. Dikensoy O, Usalan C, Filiz A. Foreign body aspiration: clinical utility of flexible bronchoscopy. Postgrad Med J 2002;78:399-403.

2. Kullar P, Yates PD. Infections and foreign bodies in ENT. Surgery. 2012 October 30; 30(11): 590-596.

3. Özdemir C, Sökücü SN, Karasulu L, Büyükkale S, Dalar L. Foreign body aspiration in adult: analysis of 28 cases. Eurasian J Pulmonol 2015; 17: 29-34.

4. Jawakar MV, Jenasamant S, Singh S, Minhas HS, Geelani MA. Late presentasion of bronchial foreign body in young adult : a case report. Clinical Medicine $2016 ; 5: 302-307$

5. Kaur Kalmajit, Sonkhya Nishi, Bapna AS. Foreign bodies in the thracheobronkhial tree : prospektif study of fifty cases. Indian Journal of Otolaryngology and Head and Neck Surgery Vol. 54 No. I, January March 2002. 